PERMANENT GENETIC RESOURCES

\title{
A set of primers for plastid indels and nuclear microsatellites in the invasive plant Heracleum mantegazzianum (Apiaceae) and their transferability to Heracleum sphondylium
}

\author{
P. HENRY,${ }^{*}$ J. PROVAN,$+J$ J. GOUDET,${ }^{*}$ A. GUISAN,$*$ Š. JAHODOVÁ $\ddagger \S$ and G. BESNARD* \\ *Department of Ecology and Evolution, Biophore, UNIL, 1015 Lausanne, Switzerland, +School of Biological Sciences, Queen's \\ University Belfast, 97 Lisburn Road, Belfast BT9 7BL, Northern Ireland, UK, $\ddagger$ Department of Ecology, Faculty of Science, Charles \\ University, Vinicná 7, Prague 2, Czech Republic, and §Institute of Botany, Academy of Sciences of the Czech Republic, CZ-252 43 \\ Pruhonice, Czech Republic
}

\begin{abstract}
This study reports the isolation and polymorphism characterization of four plastid indels and six nuclear microsatellite loci in the invasive plant Heracleum mantegazzianum. These markers were tested in 27 individuals from two distant $H$. mantegazzianum populations. Plastid indels revealed the presence of five chlorotypes while five nuclear microsatellite loci rendered polymorphism. Applications of these markers include population genetics and phylogeography of $H$. mantegazzianum. A very good transferability of markers to Heracleum sphondylium was demonstrated.
\end{abstract}

Keywords: biological invasions, indels, microsatellites, plastid DNA

Received 29 April 2007; revision accepted 19 June 2007

The giant hogweed (Heracleum mantegazzianum Sommier \& Levier; Apiaceae) is a perennial monocarpic diploid weed that successfully invaded over 20 European countries (Tiley et al. 1996). It reproduces exclusively sexually and a single plant can produce up to 50000 seeds (Pyšek et al. 2007). The ecology of giant hogweed has been thoroughly studied, yet its population genetics has lagged behind with only two studies up to date (Walker et al. 2003; Jahodová et al. 2007). Here, we describe the isolation and polymorphism characterization of four plastid indels and six nuclear microsatellite loci which may be useful for population genetic and phylogeographical studies of the species. We also tested the transferability of loci to a common close relative (Heracleum sphondylium L.) which is naturally present in the invaded range.

Hydrochory is believed to represent an important mechanism of the spread of H. mantegazzianum. Consequently, markers specific to the chloroplast genome, which are generally transmitted maternally in angiosperms, represent potentially useful tools to study seed-mediated gene flow. Plastid indels were identified by sequencing the $\operatorname{trn} \mathrm{T}-\operatorname{trn} \mathrm{L}$

Correspondence: Philippe Henry, Fax: +41-21-692-4265;

E-mail: philippe@leysin.net intergenic spacer (following Taberlet et al. 1991) on 12 H. mantegazzianum individuals from different locations. Sequencing was performed using Big Dye 3.1 Terminator cycle sequencing kit (Applied Biosystems) according to manufacturer's instructions and an ABI PRISM 3100 genetic analyser (Applied Biosystems). Primer sequences were then defined in regions flanking the four identified indels (Table 1).

Microsatellite sequences were isolated from polymerase chain reaction (PCR) products of intersimple sequence repeat (ISSR) fragments. Individual ISSR-PCR was carried out using six 5'-anchored microsatellite primers that gave clear multiband products in an initial screen in H. mantegazzianum: GGCC(AG) ${ }_{8}, \mathrm{GGCC}(\mathrm{AC})_{8}, \mathrm{CCGG}(\mathrm{AG})_{8}$, $\mathrm{CCGG}(\mathrm{AC})_{8}, \mathrm{GCGC}(\mathrm{AG})_{8}$ and $\mathrm{GCGC}(\mathrm{AC})_{8}$. Reactions were carried out in a total volume of $20 \mu \mathrm{L}$ containing 100 ng genomic DNA, 20 pmol primer, $1 \times$ PCR buffer, 200 $\mu \mathrm{M}$ each dNTP, $2.5 \mathrm{~mm} \mathrm{MgCl}_{2}$ and $1 \mathrm{U}$ Taq polymerase (Genetix) using the following parameters: initial denaturation at $94^{\circ} \mathrm{C}$ for $3 \mathrm{~min}$ followed by 35 cycles of denaturation at $94{ }^{\circ} \mathrm{C}$, annealing at $60^{\circ} \mathrm{C}$ for $1 \mathrm{~min}$, extension at $72^{\circ} \mathrm{C}$ for $1 \mathrm{~min}$ and a final extension at $72{ }^{\circ} \mathrm{C}$ for $5 \mathrm{~min}$. Ten microlitres of PCR product was resolved on a $2 \%$ agarose gel and visualized by ethidium bromide staining to ensure clarity 
Table 1 Characteristics of trnT-trnL indels (plastid DNA) and nuclear microsatellites for two populations of Heracleum mantegazzianum and Heracleum sphondylium including fluorochrome used, GenBank Accession nos, primer sequences, microsatellite motif (repeat type), annealing temperature $\left(T_{\mathrm{a}} ;\right.$ in $\left.{ }^{\circ} \mathrm{C}\right)$ and allele size range (in bp)

\begin{tabular}{|c|c|c|c|c|c|c|c|}
\hline \multirow[b]{2}{*}{ Locus } & \multirow[b]{2}{*}{ Fluorochrome } & \multirow[b]{2}{*}{ GenBank no. } & \multirow[b]{2}{*}{ Primers } & \multirow{2}{*}{$\begin{array}{l}\text { Repeat } \\
\text { type }\end{array}$} & \multirow[b]{2}{*}{$T_{\mathrm{a}}$} & \multicolumn{2}{|l|}{ Allele sizes } \\
\hline & & & & & & H. mantegazzianum & H. sphondylium \\
\hline \multicolumn{8}{|l|}{ Plastid DNA } \\
\hline trnT-L indel1 & HEX (green) & $\begin{array}{l}\text { AM493757- } \\
\text { AM493768 }\end{array}$ & $\begin{array}{l}\text { F. *AGATAAATTCTACCTGCAAGG } \\
\text { R. TGACTAGCTAATAGTAATCGC }\end{array}$ & - & 56 & 84,90 & 84,90 \\
\hline trnT-L indel2 & HEX (green) & $\begin{array}{l}\text { AM493757- } \\
\text { AM493768 }\end{array}$ & $\begin{array}{l}\text { F. *TTAGTTTTTTTCTCACATCAC } \\
\text { R. GATTTAATCTAAAAATAGAAC }\end{array}$ & - & 53 & 98,107 & 98,107 \\
\hline trnT-L indel3 & NED (yellow) & $\begin{array}{l}\text { AM493757- } \\
\text { AM493768 }\end{array}$ & $\begin{array}{l}\text { F. *TCCATCTTTACGAATCAAAG } \\
\text { R. АTTACACTTCTATATTTTATTGC }\end{array}$ & $(\mathrm{TA})_{7}(\mathrm{~T})_{7}$ & 47 & $110,112,117$ & 110,112 \\
\hline $\operatorname{trn} \mathrm{T}-\mathrm{L}$ indel 4 & HEX (green) & $\begin{array}{l}\text { AM493757- } \\
\text { AM493768 }\end{array}$ & $\begin{array}{l}\text { F. *TTCTGATTGGACCAAATGCG } \\
\text { R. TCTACCGATTTCGCCATATC }\end{array}$ & - & 53 & 214 & 147,214 \\
\hline \multicolumn{8}{|l|}{ Nuclear DNA } \\
\hline HMNSSR131 & NED (yellow) & EF654668 & $\begin{array}{l}\text { F. *GCGATTCTCGATCTGTAAGCTT } \\
\text { R. TACTATAATTCTGAACCCTAGTT }\end{array}$ & $(\mathrm{TA})_{8}$ & 57 & $124-134$ & 124 \\
\hline HMNSSR132A & FAM (blue) & EF654669 & $\begin{array}{l}\text { F. *CGATTGCTCTTCTTTTGAGCAT } \\
\text { R. AGGGTTTTGATAAAGTTAGGAAT }\end{array}$ & $(\mathrm{CT})_{7}$ & 58 & $113-115$ & $107-113$ \\
\hline HMNSSR132B & NED (yellow) & EF654669 & $\begin{array}{l}\text { F. *ATTCCTAACTTTATCAAAACCCT } \\
\text { R. AGAGAGCCAGGTTTTGTATAAC }\end{array}$ & $(\mathrm{CT})_{7}$ & 58 & $93-103$ & $88-95$ \\
\hline HMNSSR140 & NED (yellow) & EF654670 & $\begin{array}{l}\text { F. *GTATCCGGATCTGTACCTGTA } \\
\text { R. GCCTACAAAATCAAACAACTGA }\end{array}$ & $(\mathrm{TC})_{8}$ & 58 & $122-146$ & $120-152$ \\
\hline HMNSSR206 & FAM (blue) & EF654671 & $\begin{array}{l}\text { F. *GCGATTGCTCTTCTTTTGAGCA } \\
\text { R. TTGGGGTTTTGATAAAGTTAGGAA }\end{array}$ & $(\mathrm{TC})_{10}$ & 58 & $116-118$ & $110-116$ \\
\hline HMNSSR211 & HEX (green) & EF654672 & $\begin{array}{l}\text { F. *CAGCCTTCTTGTTGTTATCACCA } \\
\text { R. TGGGTGTTAGAGTTTTGAAAAAGA }\end{array}$ & $(\mathrm{CT})_{8}$ & 58 & 115 & $117-121$ \\
\hline
\end{tabular}

*Primer labelled with a fluorochrome.

of fragments. The remaining $10 \mu \mathrm{L}$ from each reaction was purified, pooled and ligated into pGEM-T (Promega) according to manufacturer's instructions. Following transformation into Escherichia coli JM109, 48 positive (white) clones were sequenced. All clones had inserts containing flanking microsatellite motifs corresponding to the anchored primer used to generate the ISSR fragment. Nine unique clones contained one internal microsatellite motif. For these, pairs of flanking primers were designed to amplify the repeated regions.

The developed markers were tested on $27 \mathrm{H}$. mantegazzianum individuals sampled in two geographically distinct locations: the western Swiss Alps $\left(46^{\circ} 35^{\prime} 17^{\prime \prime} \mathrm{N}\right.$, $7^{\circ} 03^{\prime} 68^{\prime \prime} \mathrm{E}$; invaded range) and the Caucasus Mountains of southwest Russia $\left(44^{\circ} 17^{\prime} 15^{\prime \prime} \mathrm{N}, 38^{\circ} 54^{\prime} 04^{\prime \prime} \mathrm{E}\right.$; native range). In addition, $12 \mathrm{H}$. sphondylium individuals from two Swiss populations [(i) $46^{\circ} 44^{\prime} 70^{\prime \prime} \mathrm{N}, 7^{\circ} 94^{\prime} 86^{\prime \prime} \mathrm{E}$; (ii) $46^{\circ} 33^{\prime} 94^{\prime \prime} \mathrm{N}$, $\left.7^{\circ} 92^{\prime} 10^{\prime \prime} \mathrm{E}\right]$ were also analysed. PCR was performed using a Biometra T3 Thermocycler in a total volume of $25 \mu \mathrm{L}$ containing $1 \times$ reaction buffer (GoTaq reaction buffer; 1.5 $\mathrm{mM} \mathrm{MgCl}_{2}$, pH 8.5; Promega), $200 \mu \mathrm{M}$ of each dNTP, $0.2 \mu \mathrm{M}$ of each primer, template DNA (100 ng) and 1 U GoTaq DNA polymerase (Promega). Each forward primer was labelled with one fluorescent dye (Table 1). A ratio of half-
Table 2 Number of alleles $\left(N_{\mathrm{a}}\right)$, average observed $\left(H_{\mathrm{O}}\right)$ and expected $\left(H_{\mathrm{E}}\right)$ heterozygosities at the six nuclear microsatellites for two populations of Hercaleum mantegazzianum and Hercaleum sphondylium

\begin{tabular}{|c|c|c|c|c|c|c|}
\hline \multirow[b]{2}{*}{ Locus } & \multicolumn{3}{|c|}{ H. mantegazzianum } & \multicolumn{3}{|c|}{ H. sphondylium } \\
\hline & $N_{\mathrm{a}}$ & $H_{\mathrm{O}}$ & $H_{\mathrm{E}}$ & $N_{\mathrm{a}}$ & $H_{\mathrm{O}}$ & $H_{\mathrm{E}}$ \\
\hline HMNSSR131 & 5 & 0.593 & 0.620 & 1 & - & - \\
\hline HMNSSR132A & 3 & $0.184^{*}$ & 0.354 & 2 & 0.667 & 0.400 \\
\hline HMNSSR132B & 6 & 0.431 & 0.447 & 3 & 0.500 & 0.333 \\
\hline HMNSSR140 & 2 & 0.107 & 0.099 & 8 & 0.667 & 0.592 \\
\hline HMNSSR206 & 2 & $0.148^{*}$ & 0.321 & 2 & 0.583 & 0.333 \\
\hline HMNSSR211 & 1 & - & - & 3 & 0.500 & 0.408 \\
\hline Total & & 0.293 & 0.368 & & 0.583 & 0.413 \\
\hline
\end{tabular}

*Significant excess of homozygozity $(P<0.001)$.

labelled to half-unlabelled forward primer was used in order to attain optimal amplifications. Cycling parameters were as follows: one cycle at $94{ }^{\circ} \mathrm{C}$ followed by 35 cycles of $45 \mathrm{~s}$ at $94^{\circ} \mathrm{C}, 1 \mathrm{~min}$ at annealing temperature (Tables 1 and 2), $2 \mathrm{~min}$ at $72{ }^{\circ} \mathrm{C}$, and a final cycle at $72{ }^{\circ} \mathrm{C}$ for $10 \mathrm{~min}$. PCR products were multiplexed on an ABI PRISM 3100 with 
GeneScan-350 size standard, and alleles were identified using GENEMAPPER version 3.7 (Applied Biosystems).

For microsatellites, the software FSTAT 2.9.4. (Goudet 2005) was used to test for linkage disequilibrium, deviation from Hardy-Weinberg equilibrium, as well as observed and expected heterozygosities, number of alleles and allele size range. The software MICRO-CHECKER 2.2.3. (van Oosterhout et al. 2004) was used to check for the presence of null alleles.

The combined use of the four plastid loci developed here (Table 1) enabled the identification of five chlorotypes in $H$. mantegazzianum while four chlorotypes were detected in the sample of $H$. sphondylium. In H. mantegazzianum, four chlorotypes were found in the native population, and an additional one in the invasive population. No chlorotypes were shared between the two populations, confirming strong differentiation among the two samples. The combination of these loci may be useful to follow pattern of seed dissemination in H. mantegazzianum.

Of the nine primer pairs tested to amplify microsatellites, six produced reliable amplifications and five gave polymorphism in H. mantegazzianum (Table 2). The number of alleles ranged from two to six, and average observed and expected heterozygosities were 0.293 and 0.368 , respectively. All populations sampled here did not differ significantly from Hardy-Weinberg equilibrium, yet a significant linkage disequilibrium was detected between loci HMNSSR132A and HMNSSR206, even at the 1\% nominal level. The possible presence of null alleles was detected in the same two loci (HMNSSR132A and HMNSSR206; Table 2). A successful amplification of the microsatellite loci was obtained in H. sphondylium and five of them gave polymorphism. In contrast to $H$. mantegazzianum, locus HMNSSR131 was not polymorphic but three alleles were found at the monomorphic locus HMNSSR211. Applications of these markers include population genetics and phylogeography of H. mantegazzianum as well as H. sphondylium. Furthermore, the loci described here could be useful in detecting interspecific hybrids between the two species used here as well as with other Heracleum species.

\section{Acknowledgements}

This study was supported by the Swiss national centre of competence in research (NCCR) on plant survival in natural and agricultural ecosystems. Š.J. was supported by grants AV0Z60050516 (AS CR) and 0021620828 (MSMT CR).

\section{References}

Goudet J (2005) Fstat Version 2.9.4.: A Program to Estimate and Test Population Genetics Parameters. Available from URL: http:// www2.unil.ch/popgen/softwares/fstat.htm.

Jahodová, Trybush S, Pyöek P, Wade M, Karp A (2007) Invasive species of Heracleum in Europe: an insight into genetic relationships and invasion history. Diversity and Distributions, 13, 99-114.

van Oosterhout CV, Hutchinson WF, Wills DPM (2004) MICroCHECKER: a software for identifying and correcting genotyping errors in microsatellite data. Molecular Ecology Notes, 4, 535-538.

Pyšek P, Cock M, Nentwig W, Ravn HP (2007) Ecology and Management of Giant Hogweed (Heracleum Mantegazzianum). CAB International, Wallingford, UK.

Taberlet P, Gielly L, Pautou G, Bouvet J (1991) Universal primers for amplification of three non-coding regions of chloroplast DNA. Plant Molecular Biology, 17, 1105-1109.

Tiley GED, Dodd FS, Wade PM (1996) Heracleum mantegazzianum Sommier \& Levier. Journal of Ecology, 84, 297-319.

Walker NF, Hulme PE, Hoelzel AR (2003) Population genetics of an invasive species, Heracleum mantegazzianum: implications for the role of life history, demographics and independent introductions. Molecular Ecology, 12, 1747-1756. 